\title{
КОМУНІКАТИВНІ АСПЕКТИ МІЖ ЛІКАРЯМИ ТА ПАЦІСНТАМИ ГАСТРОЕНТЕРОЛОГІЧНОГО ПРОФІЛЮ
}

\author{
Ю. М. Степанов, І. Я. Будзак, О. М. Власова \\ Дніпропетровська державна медична академія
}

\section{COMMUNICATIVE ASPECTS BETWEEN DOCTORS AND PATIENTS OF GASTROENTEROLOGIC PROFILE}

\author{
Yu. M. Stepanov, I. Ya. Budzak, O. M. Vlasova \\ Dnipropetrovsk State Medical Academy
}

\begin{abstract}
У статті представлені особливості стосунків між лікарями і паціснтами з хворобами органів травлення. Відзначена часта поширеність функціональних захворювань травлення і важливість правильного спілкування 3 пацієнтами 3 цісю патологією. Особливу увагу приділено таким питанням, як повага до пацієнта, уважне ставлення до хворого, надання пацієнту всієї необхідної інформації про його хвороби в доступній формі.
\end{abstract}

The article presents the peculiarities of interrelations between doctors and patients with digestive diseases. There has been noticed the high prevalence of functional digestive diseases and importance of right conservation with such patients. Special attention has been given to such questions as respect to patient, attention to patient and to give patient all the necessary information about his disease.

Вступ. Хвороби органів травної системи є поширеною патологією, від якої страждають пацієнти різних вікових груп. Захворюваність на гастроентерологічні хвороби постійно зростає. Важливим є вчасне та ефективне лікування хворих із зазначеною патологією.

Основна частина. Багато сказано та написано стосовно фармакологічних аспектів лікування хвороб органів травлення. Існують міжнародні та вітчизняні стандарти (протоколи), які широко використовуються. Однак, як відомо, грамотний лікар повинен лікувати не хворобу, а передусім хворого. Тому багато що залежить не лише від правильно призначеного фармакологічного лікування (хоча це $є$ обов' язковою запорукою успішного лікування), а й від встановлення між лікарем та пацієнтом довірливих стосунків. Особливо це $\epsilon$ актуальним стосовно саме хворих 3 гастроентерологічною патологією, тому що в структурі даної патології важливе місце становлять так звані функціональні хвороби органів травлення. Функціональні захворювання, зокрема такі, як синдром подразненого кишечника, функціональна диспепсія, дисфункція жовчного міхура та інші, $є$ поширеною патологією, яка уражає широкі верстви населення. Ці хвороби характеризуються тривалим перебігом, частим рецидивуванням, погіршенням якості життя хворих. При функціональних захворюваннях травного каналу важливим елементом лікування таких хворих $є$ нормалізація психоемоційного стану хворих. Тому знову ж таки багато що залежить від налагоджування добрих довірливих взаємовідносин між лікарем та пацієнтом. Необхідно зазначити, що це є важливим нелише при функціональних, але й при органічних захворюваннях, тобто при будь-якій патології.

Насамперед важливим $є$ уважне ставлення до пацієнта. Необхідно детально розпитати скарги пацієнта, довідатися анамнез. Відомо, що в гастроентерології уважне розпитування хворого дає немало інформації, яка дозволяє правильно встановити попередній діагноз, визначити подальший діагностичний та лікувальний алгоритм. Однак необхідно визнати, що уважне розпитування пацієнта також сприяє позитивному настрою хворого. Він усвідомлює, що лікар уважно детально поставився до його симптомів, отже пацієнт розуміє, що він вже “не сам на сам" із своєю хворобою. Уважне ставлення лікаря до хворого $\epsilon$ запорукою успішного його лікування. Важливим $€$ розуміння хворого, що його проблеми - це не лише його проблеми, і що лікар дійсно відверто та щиро хоче йому допомогти.

Важливим є повага лікаря до хворого. Неприпустимим $€$ зверхнє, холодне ставлення лікаря до паціє-

(С Ю. М. Степанов, І. Я. Будзак, О. М. Власова 
нта, до його хвороби. Хворі це відчувають, і це негативно впливає на результати лікування, особливо при функціональних та інших психосоматичних хворобах. Важливо, щоб лікар поважав хворого як людину, як особистість, і лікував не хворобу, а хворого. Хворі гастроентерологічного профілю з психосоматичним компонентом часто потребують просто детальної розмови з лікарем. Якщо лікар уважно вислухає такого хворого, з розумінням поставиться до його хвороби, до його проблем, це суттєво покращить психоемоційний фон пацієнта та покращить результати лікування хворого. Також лікар повинен враховувати соціально-економічний аспект. В нинішній непростій економічній ситуації не всі хворі можуть дозволити собі вартісні діагностичні та терапевтичні засоби. Завданням лікаря при цьому є досягнення “золотої середини", тобто пацієнт повинен бути обстеженим необхідним чином та отримати необхідне лікування, але при цьому щоб він витратив на це сприятливі для нього кошти.

Ще одним аспектом, який слід обговорити при цьому, є необхідність достатнього інформування хворого. Важливим $є$ не лише правильно призначені лікарем діагностичні заходи та медикаментозна терапія, але й надання хворому необхідної інформації щодо його захворювання в доступній, зрозумілій для пацієнта формі. Як відомо, більшість гастроентерологічних захворювань мають хронічний перебіг з наявністю рецидивів захворювання. І якщо хворий буде успішно пролікований в стаціонарі або поліклініці, але не отримає при цьому чітких рекомендацій стосовно подальшої модифікації стилю життя, дієтичних рекомендацій, а також необхідності підтримуючого або протирецидивного лікування, є немалий шанс, що хвороба швидко повернеться, що може хворому завдати як фізичних, так і моральних турбот. Тому під час лікування хворо- го та спостереження за ним важливо розказати йому, що у нього за хвороба, що робити, щоб вона не прогресувала, який можливий подальший іiі перебіг, що треба робити, щоб ефективно їі лікувати та запобігати iii рецидивам. На жаль, в засобах масової інформації в нашій країні інформація медичного напрямку є недостатньою, іноді суперечливою. Тому важливою є при цьому роль саме лікаря, який має розповісти хворому усю необхідну інформацію. При цьому даний аспект стосується не лише пацієнтів $з$ функціональною патологією, а більшою мірою хворих з органічними хворобами шлунково-кишкового тракту. Лікарю треба дати хворому зрозуміти необхідність уважного ставлення пацієнта до власного здоров' я. Особливо це стосується хвороб, які часто не супроводжуються явною клінічною симптоматикою, проте становлять в собі потенційну небезпеку (наприклад, хронічний гепатит, дисліпідемія, цукровий діабет II типу, артеріальна гіпертензія та інші). Важливим є спрямування роботи лікаря не лише на лікування хворого, але й на профілактику захворювань.

Слід зазначити необхідність більшої уваги до етичних аспектів лікування хворих при навчанні лікарів на курсах післядипломної освіти. Лікарі при навчанні не лише повинні отримати сучасну інформацію про досягнення медицини останніх років, алей не забувати, що уважне та поважне ставлення лікаря до хворого $\epsilon$ значною допомогою в ефективності його діагностики та лікування.

Висновок. Грамотний лікар має лікувати хворого, а не лише хворобу. При цьому необхідним є повага до пацієнта, розуміння його проблем, достатнє інформування хворого, намагання щиро допомогти йому. Такий підхід в комбінації з високопрофесійними діагностикою та лікуванням хворого дозволить досягти максимальних успіхів в лікуванні. 